\title{
THE IMPACT OF NATIONAL HEALTH INSURANCE POLICY ON OUTPATIENT VISIT IN MALUKU AND PAPUA: LOGIT MODEL
}

\author{
*Rira Wahdani Martaliza, **Pujiyanto
}

\begin{abstract}
* Health Policy and Administration, Faculty of Public Health, Universitas Indonesia, Kampus Depok, Jawa Barat, 16425 , Indonesia

** Health Policy and Administration, Faculty of Public Health, Universitas Indonesia, Kampus Depok, Jawa Barat, 16425, Indonesia
\end{abstract}

Email: rirawahdani13@gmail.com

\begin{abstract}
The National Health Insurance (JKN) is one manifestation of the National Social Security System program which aims to provide benefits for health care and protection. This study uses secondary data from the 2017 National Socio-Economic Survey (Susenas) which aims to prove that JKN ownership has an influence on outpatient visits. The research respondents were all people who were registered as JKN participants in the Maluku and Papua Islands regions as many as 77.307 people. This study uses the econometric approach with the Logit regression model. The results showed that JKN was positively associated with outpatient visits, with coefficients of PBI $(0,713)$ and Non PBI $(0,807)$. The results also showed that age had a positive effect on outpatient visits with a coeficent value $(0,406)$, gender had a positive effect on outpatient visits with a coefficient $(0,146)$, employment status negatively affected outpatient visits with a coefficient value $(-0,198)$ likewise the health status has a positive effect on outpatient visits with a coefficient $(3,914)$. JKN ownership has an important role for the community in fulfilling the utilization of health facilities when suffering from health complaints, one of which is the use of outpatient visits.
\end{abstract}

Keywords: jkn, outpatient, logit

\begin{abstract}
Abstrak. Jaminan Kesehatan Nasional (JKN) merupakan salah satu wujud dari program Sistem Jaminan Sosial Nasional yang bertujuan untuk memberikan manfaat pemeliharaan dan perlindungan kesehatan. Penelitian ini menggunakan data sekunder Survei Sosial Ekonomi Nasional (Susenas) tahun 2017 yang bertujuan untuk membuktikan bahwa kepemilikan JKN memberikan pengaruh terhadap kunjungan rawat jalan. Responden penelitian adalah seluruh masyarakat yang berada di wilayah Kepulauan Maluku dan Papua yang memenuhi kriteria inklusi sebanyak 77.307 orang. Penelitian ini menggunakan pendekatan ekonometrika dengan model regresi Logit. Hasil penelitian menunjukkan bahwa JKN berhubungan positif dengan kunjungan rawat jalan, dengan nilai koefisien PBI (0,713) dan Non PBI (0,807). Hasil penelitian juga menunjukkan bahwa umur berpengaruh positif terhadap kunjungan rawat jalan dengan nilai koefisin (0,406), jenis kelamin berpengaruh positif terhadap kunjungan rawat jalan dengan nilai koefisien (0,146), status pekerjaan berpengaruh negatif terhadap kunjungan rawat jalan dengan nilai koefisien (-0,198), begitu juga dengan status kesehatan berpengaruh positif terhadap kunjungan rawat jalan dengan koefisien (3,914). Kepemilikan JKN memiliki peranan penting bagi masyarakat dalam memenuhi pemanfaatan fasilitas kesehatan ketika menderita keluhan kesehatan, salah satunya dengan pemanfaatan kunjungan rawat jalan.
\end{abstract}

Kata kunci: jkn, rawat jalan, logit

\section{INTRODUCTION}

In implementing social insurance, the Indonesia government creates a national social insurance system policy called National Health Insurance (JKN). National Health Insurance (JKN) is a health protection insurance for its participants by providing health care benefits and protection of basic health needs where the health insurance is run by the Health Insurance Administering Agency (BPJS) since January 1, 2014.
Health care and protection of basic health needs provided by the JKN program are health services in the form of outpatient and inpatient health services. Outpatient health services are provided by public health facilities and private health facilities in collaboration with BPJS. Health services in the JKN program follow a tiered referral system, which means that all JKN participants who require health services are not 
permitted to use advanced services without making the first visit to a first-level health facility or without referral except in an emergency (1).

Based on data from the Central Statistics Agency (BPS), the number of poor people in Indonesia in September 2017 reached 26.58 million people or around $10.12 \%$ of the population. The most significant percentage of the sparse population is in the Maluku Islands and Papua, which is $21.23 \%$ (2).

Based on Riskesdas 2013, 10.4\% of Indonesia's population paid outpatient visits. Coverage of outpatient service utilization in the regions of West Papua, Maluku, and North Maluku is still below the national average that is $5 \%-10 \%$, while the Papua region is the region with the second-highest number of outpatient services utilization in Indonesia after Yogyakarta DIY (3).

The treatment behavior itself is one reason for someone not to make outpatient visits to health facilities. Based on the 2013 Riskesdas report, the proportion of Indonesians who do self-medication is $26.4 \%$. This self-medication behavior is higher than the behavior of outpatient visits in Indonesia, which is only around $10.4 \%$, with a self-medication population of Papua region is $8.7 \%$, West Papua, Maluku, and North Maluku is also doing self-treatment in the range of $20 \%$ $-25 \%$.

Based on studies conducted using Susenas data for 2011-2016 regarding health service utilization trends, there is an increase in the utilization of outpatient use in the first year of JKN (2014-2015) by $16 \%$, whereas in previous years (2011-2013) utilization of health services tend to be stable. However, there is still an imbalance where the use of outpatient care is $24 \%$ higher in the insured middle-high income community compared to the insured lower-middle community (4).

With those problems, this study aims to find out whether the JKN program can improve the use of outpatient care for all levels of society, especially the poor.

This study is conducted to look at the effect of the JKN program on outpatient visits in Indonesia, especially in participants from impoverished and poor communities. Also, this study aims to look at the phenomenon of selfmedication behavior undertaken by the community, which is one of the reasons for not doing the outpatient treatment.

\section{METHODS}

This study uses a quantitative approach with crosssectional study design. The type of data used in this study is secondary data from the National SocioEconomic Survey (Susenas) in 2017. The study population is all people who are in the Maluku Islands and Papua who are respondents to the Susenas in 2017. The research sample amounted to 77,307 people, which included in the inclusion criteria of this study. The inclusion criteria were respondents who did and did not visit outpatient visits to health facilities. The exclusion criteria in this study were respondents who did not answer all questions (missing data). Data were analyzed using univariate, bivariate, and multivariate analysis using the econometric approach using the Binary Regression model, which is the Logit regression analysis method. Logit Regression aims to find the probability of the effect of national health insurance and other control variables on outpatient utilization.

\section{RESULTS AND DISSCUSION}

\section{Results}

Univariate analysis results show that outpatient visits in the Maluku Islands and Papua in 2017 is $6.24 \%$. Based on the health insurance variable, there are still many people who have not registered as JKN participants, which are 23,832 people $(30.83 \%)$. Most respondents are aged $>35$ years, with the total number is 50,456 people $(65.27 \%)$, and the male population is 40,443 people $(52.31 \%)$. Many respondents are still at a low level of education; it counted to 56,413 people $(72.97 \%)$. People who are not using internet access are 62,609 people $(80.99 \%)$. Respondents with nonworking status were 40,956 people $(52.98 \%)$. In populated rural areas $(54,103$ people $(69.98 \%))$, the highest number of economic status was wealthy, which are $17,277(22.35 \%)$, but people who experienced health problems reached 7,347 people $(9.50 \%)$ (Table 1).

Tabel 1. Outpatient Visit Univariate Analysis in Maluku and Papua in 2017 


\begin{tabular}{lrr}
\hline \multicolumn{1}{c}{ Variable } & $\mathrm{n}$ & $\%$ \\
\hline Outpatient visit & & \\
\hline No & 72.485 & 93,76 \\
Yes & 4.822 & 6,24 \\
\hline JKN registration & & \\
\hline Does not have any insurance & 23.832 & 30,83 \\
PBI & 23.333 & 30,18 \\
Non-PBI & 7.823 & 10,12 \\
Jamkesda & 20,951 & 27,10 \\
Private insurance & 1.368 & 1,77 \\
\hline Age & & \\
\hline >35 years old & 50.456 & 65,27 \\
$\leq 35$ years old & 26.851 & 34,73 \\
\hline Sex & & \\
\hline Male & 40.443 & 52,31 \\
Female & 36.864 & 47,69 \\
\hline Educational level & & \\
\hline High & 56.413 & 72,97 \\
Low & 20.894 & 27,03 \\
\hline Acoess to internet & & \\
\hline No & 62.609 & 80,99 \\
Yes & 14.698 & 19,01 \\
\hline Employment Status & & \\
\hline Unemployed & 40.956 & 52,98 \\
Employed & 36.351 & 47,02 \\
\hline Area & & \\
\hline Rural & 54.103 & 69,98 \\
Urban & 23.204 & 30,02 \\
\hline Economic Status & & \\
\hline Low Income & 14.34 .223 & 18,40 \\
Low-Middle Income & 14.380 & 18,60 \\
Middle Income & 15.503 & 20,05 \\
Middle-High Income & 15.924 & 20,60 \\
High Income & 17,277 & 22,35 \\
\hline Health Status & & \\
\hline Healthy & & \\
III & & \\
\hline Total & & \\
\hline & & \\
\hline
\end{tabular}

The results of the bivariate analysis between the independent variables and the dependent variable outpatient visits showed that the respondents who made the most outpatient visits were private insurance participants $(9.43 \%)$, and the least of participants who did outpatient visits did not have any health insurance ( 3.90), with a p-value of $0.0001<0.05$ which means there is a relationship between JKN ownership and outpatient visits. Respondents who did outpatient visit are mostly from the age group of $<35$ years old $(9.22 \%)$, and respondents who rarely did outpatient visit were from the unproductive age group $(4.65 \%)$ with a p-value of $0.0001<0.05$ which means there is a relationship between age with outpatient visits. Women did outpatient visits $(6.78 \%)$ more frequently than men $(5.74 \%)$ with a p-value of $0.0001<0.05$, which means there is a relationship between sex and outpatient visits. People with low educational status are more often to do outpatient visits $(6.50 \%)$ compared to the high education people $(5.53 \%)$ with a p-value of $0.0001>$ 0.05 , which means there is a relationship between the level of education with outpatient visits. Respondents who do not have access to the internet did more outpatient visits $(6.38 \%)$ compared to those who have access $(5.63 \%)$, with a p-value of $0.001<0.05$, which means there was a relationship between internet access and outpatient visits. Respondents who did not work did more outpatient visits (6.38\%) compared to those who worked $(1,661$ people, $6.06 \%)$ with a p-value of $0.059>0.05$, which meant that there was no relationship between work status and outpatient visits (Table 2).
Respondents who live in urban areas do more outpatient visits $(6.89 \%)$ than those who live in rural areas $(5.96 \%)$ with a p-value of $0.0001<0.05$, which means there is a relationship between locations and outpatient visits. Respondents from a wealthy economic status do more outpatient visits $(8.20 \%)$ than people from poor economic status (757 people, 5.65\%) with a p-value of $0.0001<0.05$, which means there is a relationship between economic status and outpatient visits. Respondents who have health problems do more outpatient visits $(6.24 \%)$ compared to those who do not have $(1.79 \%)$ with a $p$-value of $0.0001<0.05$, which means there was a relationship between morbidity and visits outpatient (Table 2).

Table 2. Outpatient Visit Bivariate Analysis in Maluku and Papua in 2017

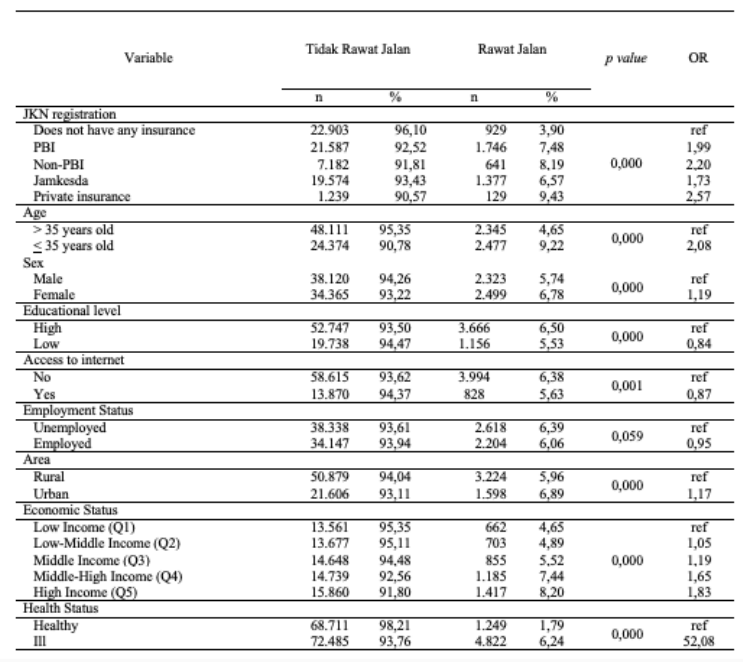

There is an intriguing result from the bivariate analysis between health insurance variables and economic status. From the results of the bivariate analysis, it shows that there are still people from the rich economic status registered as PBI participants, namely $31.01 \%$ (Table 3).

Tabel 3. Bivariate Analysis on Health Insurance with Economic Status in Maluku and Papua in 2017

\begin{tabular}{|c|c|c|c|c|c|c|c|c|c|c|c|}
\hline \multirow[t]{2}{*}{ Variable } & \multicolumn{2}{|c|}{$\begin{array}{l}\text { No health } \\
\text { insurance }\end{array}$} & \multicolumn{2}{|c|}{ PBI } & \multicolumn{2}{|c|}{ Non PBI } & \multicolumn{2}{|c|}{ Jamkesda } & \multicolumn{2}{|c|}{$\begin{array}{c}\text { Private } \\
\text { Insurance }\end{array}$} & \multirow[t]{2}{*}{ p value } \\
\hline & $n$ & $\%$ & $n$ & $\%$ & $\frac{n}{n}$ & $\%$ & $n$ & $\%$ & $n$ & $\%$ & \\
\hline $\begin{array}{l}\text { Economic Status } \\
\text { Low Income } \\
\text { Low-Middale }\end{array}$ & $\begin{array}{l}4.0 .15 \\
5.026\end{array}$ & $\begin{array}{l}{ }_{28.23} 8.95 \\
349\end{array}$ & $\begin{array}{l}{ }_{4.277}^{4.445} \\
4.45\end{array}$ & $\begin{array}{l}30.07 \\
30.91\end{array}$ & $\begin{array}{l}569 \\
751\end{array}$ & $\begin{array}{l}4.00 \\
5,22\end{array}$ & 5.312 & 37,35 & $\begin{array}{l}50 \\
64\end{array}$ & $\begin{array}{l}0.35 \\
0,45\end{array}$ & \\
\hline $\begin{array}{l}\text { Income } \\
\text { Middle Income }\end{array}$ & 5.708 & 36.82 & 4.766 & 30,74 & 1249 & 8,06 & $\begin{array}{l}4.0464 \\
3.667\end{array}$ & $\begin{array}{l}23,465 \\
23,65\end{array}$ & 113 & 0,73 & 0,000 \\
\hline $\begin{array}{l}\text { Middle-High } \\
\text { lntoomc }\end{array}$ & 5.015 & 31,49 & 4.938 & 31,01 & 1.723 & 10,82 & 3.997 & 25,10 & 251 & 1,58 & \\
\hline $\begin{array}{l}\text { High lncome } \\
\end{array}$ & 4.068 & 23,55 & 4.907 & 28,40 & 3531 & 20.44 & 3.881 & 22.46 & 890 & 5.15 & \\
\hline
\end{tabular}

The results of the Logit analysis show that Health Insurance has a significant influence and increases the utilization of outpatient health services. JKN (PBI) increases the probability of using outpatient health services by 2.04 times compared to those without health insurance. Age has a significant influence and can increase the utilization of outpatient health 
services, where every 1-year increase in respondent's age will have a higher possibility of making outpatient visits by 1.50 times (Table 4 ).

Gender has a significant influence and can increase the utilization of outpatient health services where female respondents have a higher likelihood to do outpatient visits than male respondents by 1.16 times. Employment status has a significant influence and can reduce the utilization of ambulatory health services, where respondents who work can reduce the utilization of ambulatory health services by 0.82 times compared to respondents who do not work. (Table 4).

Respondents with wealthy economic status have a significant effect on outpatient visits. They can increase the utilization of outpatient health services by 1.36 times (middle-up income) and 1.39 times (high income) compared to respondents with low-income economic status. Health status has a significant effect and can increase the utilization of outpatient health services where respondents who experience health problems are more likely to make outpatient visits by 50.08 times compared to respondents who do not have health problems. The variables that did not significantly influence the utilization of ambulatory health services were the level of education, internet access, location of residence, and economic status of the very poor, poor, and middle-income class (Table 4).

Tabel 4. Logit Regression Analysis on Outpatient in Maluku and Papua in 2017

\begin{tabular}{|c|c|c|c|}
\hline Variable & $\begin{array}{r}\text { Logi } \\
\end{array}$ & & \\
\hline \multirow{2}{*}{\multicolumn{4}{|c|}{ JKN registration }} \\
\hline Does not have any insurance & & & \\
\hline & ref & & \\
\hline $\mathrm{PBI}$ & $0,713 * * *$ & 2,04 & 0,000 \\
\hline Non-PBI & $0,807 * * *$ & 2,24 & 0,000 \\
\hline Jamkesda & $0,861 * * *$ & 2,36 & 0,000 \\
\hline Private insurance & $1,015 * * *$ & 2,76 & 0,000 \\
\hline \multicolumn{4}{|l|}{ Age } \\
\hline $\begin{array}{l}>35 \text { years old } \\
<35 \text { years old }\end{array}$ & ref & 1,50 & 0,000 \\
\hline \multicolumn{4}{|l|}{ Sex } \\
\hline $\begin{array}{l}\text { Male } \\
\text { Female }\end{array}$ & $\begin{aligned} \mathrm{ref} \\
0.14 * * .\end{aligned}$ & 1,16 & 0,000 \\
\hline \multicolumn{4}{|l|}{$\begin{array}{l}\text { Educational level } \\
\end{array}$} \\
\hline High & ref & 0,93 & 0,143 \\
\hline \multicolumn{4}{|l|}{ Access to internet } \\
\hline $\begin{array}{l}\text { No } \\
\text { Yes }\end{array}$ & ref & 0,90 & 0,079 \\
\hline \multicolumn{4}{|l|}{$\begin{array}{l}\text { Employment Status } \\
\end{array}$} \\
\hline $\begin{array}{l}\text { Unemployed } \\
\text { Employed }\end{array}$ & $\begin{array}{c}\text { ref } \\
-0,198 * * *\end{array}$ & 0,82 & 0,000 \\
\hline \multicolumn{4}{|l|}{ Area } \\
\hline $\begin{array}{ll}\text { Rural } \\
\end{array}$ & $\begin{array}{c}\text { ref } \\
\text { ref }\end{array}$ & 1,07 & 0,089 \\
\hline \multicolumn{4}{|l|}{$\begin{array}{l}\text { Economic Status } \\
\end{array}$} \\
\hline Low Income & ref & & \\
\hline Low-Middle Income & $-0,020$ & 0,98 & 0,766 \\
\hline Middle Income & 0,038 & 1,04 & 0,547 \\
\hline Middle-High Income & $0,304 * * *$ & 1,36 & 0,000 \\
\hline High Income & $0,334^{* * *}$ & 1,39 & 0,000 \\
\hline \multicolumn{4}{|l|}{ Health Status } \\
\hline Healthy & $\begin{array}{c}\text { ref } \\
3.94 * * . *\end{array}$ & 50,08 & 0,000 \\
\hline$\frac{\text { III }}{\text { Constant }}$ & $\frac{3,914}{-4,884}$ & 0,000 & 0,000 \\
\hline Observation & 77.307 & - & \\
\hline
\end{tabular}

\section{Disscusion}

The results of the study show that the number of respondents who did outpatient visits are $6.24 \%$, and those who did not do outpatient visits because of selfmedication reasons were $93.76 \%$. This result is in line with the results of the 2010 Riset Kesehatan Dasar, which states that there are still households that do self- treatment when they are ill $(55.8 \%)$, and the remainder would seek treatment from the health services if they are ill (5). According to the 2013 Riset Kesehatan Dasar, there are still households that store medicines for self-medication (35.2\%) (3). This is in line with research conducted by Wira (2018), which shows that there is an increase in self-medication behavior among JKN participants because there are many facilities that are making it easier for mothers to treat themselves rather than going to health facilities (6).

Table 3 shows that there are respondents from highincome economic status registered as PBI and Jamkesda participants. Studies conducted by Rolindrawan (2015) revealed that there are still inaccuracies in JKN membership, especially PBI, where PBI participants should be participants who come from very poor and poor communities whose insurance premiums were paid by the Government. For this reason, we suggest the Government does PBI membership targeting program more accurately. Local governments can accommodate people who can not afford to pay the premium to be registered as Jamkesda participants and integrated with JKN / KIS. JKN ownership has a significant effect on outpatient visits. This result is in line with research conducted by Masytoh (2018), who revealed that ownership of health insurance could increase access to outpatient health services (8). Research conducted by Purbaningsih (2017) also supports this result in which they stated that the Askeskin / Jamkesmas program increases outpatient visits both at the Puskesmas and at the Hospital (9).

Age has a significant impact on the utilization of health services. As people get old, there would be a decrease in the health condition of one's body. This study shows that the age variable has a significant impact on outpatient visits, which is in line with research conducted by Rolindrawan (2015), showing that age has a significant influence on outpatient visits (7).

Various studies stated that women use more health services than men, which is related to the high morbidity of women compared to men and the differences in health perceptions between women and men. This study shows that gender variables significantly influence outpatient visits, which is in line with research conducted by Rolindrawan (2015) that gender significantly influences outpatient visits (7).

The higher one's education level, the higher their knowledge about recognizing the initial symptoms of the disease; thus, the more significant one willingness to seek health services. Highly educated people can quickly know a variety of symptoms of diseases from various sources. In this study, the level of education did not significantly influence outpatient visits. However, in a study conducted by Oktafianti (2016) 
showed that the level of education was significantly related to outpatient access (10). This result is due to the significant difference between the proportion of respondents with low education and highly educated respondents resulting in an uneven distribution of respondents. Even though children under the age of 15 are categorized as having low education, outpatient visits are still a decision of parents with higher educational levels. The results of this study are in line with research conducted by Bambang Irawan and Asmaripa (2018), which states that the level of education is not significantly related to outpatient visits (11).

With the rapid advancement of technology, getting information on various things on the internet is easy, including health information. When there are family members or relatives who experience health problems, then there will be a very strong desire to dig up health information through the internet. In this study, internet access had no effect on outpatient visits. This is because the majority of respondents did not have access to the internet, allegedly because of the limited reach of internet access in the Maluku and Papua islands, which are mostly rural areas. But the results of a study conducted by Hsieh et al. (2016) found that internet use was significantly associated with increasing outpatient visits to health facilities (12)

Work affects a person's behavior in utilizing health services. If someone is ill, it will disturb his/her work, which later can affect the income. This study shows that the employment status variable significantly influences outpatient visits, which is in line with research conducted by Masytoh (2018) that states work status is significantly related to outpatient visits (8).

Differences in the characteristics of urban areas can increase the likelihood of utilizing health facilities. In urban areas, there are various kinds of facilities that make it easy for the community to access various needs, such as outpatient health facilities. This study shows that location variables do not significantly influence outpatient visits. This result is because most of the Maluku Islands and Papua are rural areas, which results in very different proportions between rural and urban areas. However, research conducted by Rolindrawan (2015) stated that the location of residence significantly influences outpatient visits (7). That result is also in line with the research conducted by Nugraheni et al. (2017), which stated that people who live in urban areas have more access to outpatient facilities than those who live in rural areas (13).

The consumption pattern of a country's population reflects the socioeconomic conditions of the area. The expenditure quintile can be used to measure the level of prosperity of the population. The quintile is divided into five groups, from the smallest to the largest obtained from the average expenditure per capita. The higher the level of expenditure quintile, the more prosperous the people (14). So that high-income people will have greater expenditure on health services.

This study shows that the economic status variable does not significantly influence outpatient visits (only the significant middle-high income and high-income economic status), which in line with research conducted by Oktarina (2010) that economic status does not significantly influence outpatient visits (15). This result is supported by Astuti's research (2018), which states that there is no significant relationship between income and outpatient visit access (16). This result also indicates that the community, especially the lower-income, has not enjoyed the impact of the JKN program in protecting financial risks due to health costs.

People who have health problems are more likely to seek health services than healthy people. So that health factors have a very close relationship with the utilization of health services. This study shows that respondents who have health problems significantly influence outpatient visits, which is in line with research conducted by Oktarina (2010), which shows that pain complaints significantly affect outpatient visits (15).

\section{CONCLUSION}

This study concludes that the JKN program affects the utilization of outpatient visits even though there is still an imbalance in the economic status where people from middle-high income and high-income economies have more impact on the utilization of outpatient visits. This study also shows that there are still people from the middle-high income and high-income economies who are registered as PBI participants, thus an evaluation from the central and regional government is needed to meet the targets of PBI participants.

\section{ACKNOWLEDGMENT}

High gratitude to Prof. Budi Hidayat, SKM, MPPM, Ph.D., who has provided much knowledge about health econometrics. Also, to Dr. Pujiyanto, SKM, MKes, as an academic supervisor who has been willing to guide this research so that this research is complete.

\section{REFERENCES}

1. Peraturan Menteri Kesehatan RI. Pelayanan Kesehatan pada Jaminan Kesehatan Nasional. 2013.

2. Badan Pusat Statistik RI. Profil Kemiskinan di 
Indonesia. 2018.

3. Badan Litbang Kemenkes RI. Riset Kesehatan Dasar Tahun 2013. 2013.

4. Health Policy Plus dan Tim Nasional Penanggulangan Kemiskinan Indonesia. Tren Pemanfaatan Pelayanan Kesehatan dalam Implementasi Jaminan Kesehatan Nasional: 2011 - 2016 Metode dan Data Faktor-faktor yang Mempengaruhi Pemanfaatan Pelayanan Kesehatan. 2018.

5. Badan Litbang Kemenkes RI. Riset Kesehatan Dasar Tahun 2010. 2010.

6. Wira HS. Sudahkah Jaminan Kesehatan Nasional digunakan oleh Ibu di Indonesia? J Kebijak Kesehat Indones. 2018;07(04):154-7.

7. Rolindrawan D. The Impact of BPJS Health Implementation for the Poor and Near Poor on the Use of Health Facility. Procedia - Soc Behav Sci [Internet]. Elsevier B.V.; 2015;211(September):550-9. Available from: http://linkinghub.elsevier.com/retrieve/pii/S18 77042815054130

8. Masytoh LS. Hubungan Kepemilikan Jaminan Kesehatan dengan Pemanfaatan Fasilitas Kesehatan Formal Untuk Rawat Jalan di Indonesia. Universitas Indonesia; 2018.

9. Purbaningsih A. Dampak Jaminan Kesehatan Sosial bagi Masyarakat Miskin terhadap Utilisasi Layanan Kesehatan (Data Indonesia Family Life Survey 2000, 2007, dan 2004). Universitas Indonesia; 2017.

10. Oktafianti Y. Analisis Ekuitas Utilisasi Pelayanan Rumah Sakit pada Implementasi Awal Program JKN di Indonesia Tahun 2014 (Susenas 2014). Universitas Indonesia; 2017.

11. Bambang Irawan AA. ANALISIS FAKTORFAKTOR YANG BERHUBUNGAN DENGAN PADA PESERTA JAMINAN KESEHATAN NASIONAL DI WILAYAH KERJA PUSKESMAS PAYAKABUNG, KABUPATEN OGAN ILIR. J Ilmu Kesehat Masy. 2018;9(November):189-97.

12. Ronan Wenhan HLCT-FCJ-CLT-BLY-YCCCT. The Association Between Internet Use and Ambulatory Care-Seeking Behaviors in Taiwan: A Cross-Sectional Study. J Med Internet Res. 2016;18(12).

13. Nugraheni WP, Hartono RK. Analisis Pola Layanan Kesehatan Rawat Jalan pada Tahun Pertama Implementasi Program Jaminan Kesehatan Nasional (JKN). Media Penelit dan Pengemb Kesehat [Internet]. 2017;27(1):9-16. Available from: http://ejournal.litbang.kemkes.go.id/index.php/
MPK/article/view/6000

14. Badan Pusat Statistik RI. Pengeluaran untuk Konsumsi Penduduk Indonesia per Provinsi. 2017.

15. Oktarina S. Studi Pemanfaatan Rawat Jalan di Institusi Pelayanan Kabupaten Dharmasraya dan Kota Sawahlunto Provinsi Sumatera Barat (Analisis Lanjut Data Susenas 2007 dan Riskesdas 2007). Universitas Indonesia; 2010.

16. Astuti SD. Hubungan Jaminan Kesehatan dengan Akses Rawat Jalan dan Rawat Inap pada Kelompok Penderita Penyakit Tidak Menular (PTM): Analisis Data Indonesia Family Life Survey 2014. Universitas Indonesia; 2018. 